\title{
Acute Toxicity of Zinc on Southern Medicinal Leech, Hirudo verbana Carena, 1820
}

\author{
Mustafa CEYLAN ${ }^{1,2 *}$, Osman ÇETINKAYA ${ }^{2}$, Cafer BULUT $^{3}$ B \\ ${ }^{1}$ Isparta University of Applied Sciences, Medicinal Leech Application and Research Center, Isparta/Turkey \\ ${ }^{2}$ Isparta University of Applied Sciences, Eğirdir Fisheries Faculty, Isparta/Turkey \\ ${ }^{3}$ Republic of Turkey Ministry of Agriculture and Forestry, Fisheries Research Institute, Eğirdir-Isparta/Turkey \\ * Corresponding author: mustafaceylan@isparta.edu.tr
}

Received 04 February 2021; Accepted 16 June 2021; Release date 01 September 2021.

How to Cite: Ceylan, M., Çetinkaya, O., \& Bulut, C. (2021). Acute toxicity of zinc on Southern Medicinal Leech, Hirudo verbana Carena, 1820. Acta Aquatica Turcica, 17(3), 421-428. https://doi.org/10.22392/actaquatr.874241

\begin{abstract}
In the present study it was aimed to determine the acute toxicity of zinc on southern medicinal leech Hirudo verbana Carena, 1820 that is used in ecotoxicological studies. The experiment was conducted for 96 hours using the semi-static bioassay method with replicate two times. The leeches were exposed to zinc concentrations of $6.25 \mathrm{mg} / \mathrm{L}, 12.50 \mathrm{mg} / \mathrm{L}, 25$ $\mathrm{mg} / \mathrm{L}, 50 \mathrm{mg} / \mathrm{L}, 100 \mathrm{mg} / \mathrm{L}$ and $200 \mathrm{mg} / \mathrm{L}$, respectively. As a result of the experiment, the $L C_{50}$ values for $24,48,72$, and 96 hours were determined $48.30 \mathrm{mg} / \mathrm{L}, 19.68 \mathrm{mg} / \mathrm{L}, 15.48 \mathrm{mg} / \mathrm{L}$, and $14.12 \mathrm{mg} / \mathrm{L}$, respectively. The $L T_{50}$ values for $25 \mathrm{mg} / \mathrm{L}, 50$ $\mathrm{mg} / \mathrm{L}, 100 \mathrm{mg} / \mathrm{L}$ and $200 \mathrm{mg} / \mathrm{L}$ zinc concentrations were determined 38.63 hours, 24.55 hours, 14.62 hours, and 12.78 hours, respectively. Defecation, intensive mucus output, uncontrolled swimming, attempt to escape from the experiment media, reducing the cling power, coiling (buckling), vomiting the digestive blood, the body deformations, penile prolapse, hemorrhage, and abrasion in the wall of the body were the main physiological and behavioral responses in the leeches which were exposed to the different zinc solutions. The data obtained revealed that the zinc sensitivity of $H$. verbana was moderate when compared to other organisms. It is expected that the data of the present study will contribute to the management of endangered medicinal leech populations.
\end{abstract}

Keywords: heavy metal, bioassay, mortality, $L C_{50}, L T_{50}$.

Çinkonun Güney Tıbbi Sülüğü Hirudo verbana Carena, 1820 Üzerine Akut Toksisitesi

Özet

$\mathrm{Bu}$ çalışma ile çinkonun ekotoksikolojik çalışmalarda kullanılmakta olan güney tıbbi sülüğü Hirudo verbana Carena, 1820 üzerine akut toksisitesinin belirlenmesi amaçlanmıștır. Deneme 96 saat süreli yarı statik biyodeney yöntemiyle iki tekerrürlü yürütülmüştür. Bu amaçla, sülükler $6,25 \mathrm{mg} / \mathrm{L}, 12,50 \mathrm{mg} / \mathrm{L}, 25 \mathrm{mg} / \mathrm{L}, 50 \mathrm{mg} / \mathrm{L}, 100 \mathrm{mg} / \mathrm{L}$ ve $200 \mathrm{mg} / \mathrm{L}$ 'lik çinko konsantrasyonlarına maruz bırakılmıştır. Deney ve hesaplamalar sonucunda $L C_{50}$ değerleri $24,48,72$ ve 96 . saatler için sirasiyla $48,30 \mathrm{mg} / \mathrm{L}, 19,68 \mathrm{mg} / \mathrm{L}, 15,48 \mathrm{mg} / \mathrm{L}$ ve $14,12 \mathrm{mg} / \mathrm{L}$ olarak belirlenmiştir. $25 \mathrm{mg} / \mathrm{L}, 50 \mathrm{mg} / \mathrm{L}, 100 \mathrm{mg} / \mathrm{L}$ ve 200 $\mathrm{mg} / \mathrm{L}$ konsantrasyonları için belirlenen $L T_{50}$ değerleri sırasıyla 38,63 saat, 24,55 saat, 14,62 saat ve 12,78 saat olarak hesaplanmıştır. Çinkoya maruz kalmış sülüklerde dışkılama, aşırı mukus çıkışı, kontrolsüz yüzme, ortamdan uzaklaşma girişimleri, tutunma gücünün zayıflaması, kıvrılma (burkulma), sindirilmiş kanın kusulması, vücutta oluşan deformasyonlar, erkeklik organının dışa sarkması, hemoraji ve vücut duvarında aşınmalar başlıca fizyolojik ve davranışsal tepkileri oluşturmuştur. Elde edilen veriler, diğer organizmalarla kıyaslandığında $H$. verbana türünün çinko duyarlılığının orta düzeyde olduğunu ortaya koymuştur. $\mathrm{Bu}$ çalışmada elde edilen verilerin nesli tehlike altında olan tıbbi sülük popülasyonlarının yönetimine katkı sağlaması beklenmektedir.

Anahtar Kelimeler: ağır metal, biyodeney, mortalite, $L C_{50}, L T_{50}$.

\section{INTRODUCTION}

Medicinal leeches have been used to treat some diseases of both humans and animals in both traditional and modern medicine, as well as in veterinary (Gödekmerdan et al., 2011; Mumcuoglu, 2014; Sobczak and Kantyka, 2014). The enzymes secreted by medicinal leeches are used in the production of some drugs and cosmetic products (Ayhan and Mollahaliloğlu, 2018; Lemke and Vilcinskas, 2020; Shakouri and Wollina, 2021). Medicinal leeches play some important roles in aquatic ecosystems (Ceylan et al., 2015); however, because of over-collection and habitat destruction, medicinal leech populations have been weakening day by day in many wetlands (Sağlam, 2011; 
Ceylan and Çetinkaya, 2017, Sağlam, 2018). It is a necessity, therefore, to take protective measures for the sustainable management of medicinal leech populations.

Heavy metals affect both environments and organisms (Mishra et al., 2019) causing toxic effects (Tchounwou et al., 2012). Aquatic toxicology has increasing importance for aquatic ecosystems as well as for all organisms. Research in this field has now become a necessity (Çetinkaya, 2005).

The heavy metals lead to an activity decreases in invertebrates (Wicklum et al., 1997). Zinc, as an essential trace element for all organisms (Eisler, 1993; Salgueiro et al., 2000), is a heavy metal found in the highest concentrations in wastewaters of the majority of the modern industrialized societies (Boardman and McGuire, 1990), and its concentration is increasing due to the effects of both natural and anthropogenic factors (Özkul, 2008). The erosion of the rocks in the earth's crust, the wastewater originated the industrial and urban discharges, and mining activities are the main sources of zinc in natural waters (Sönmez and Çetinkaya, 2003; Kori-Siakpere and Ubogu, 2008). The discharge of high zinc concentrations in aquatic ecosystems causes a decrease in the number of individuals of many species of macro-invertebrates including the leeches (Willis, 1979). Zinc leads the aquatic organisms to death with its cytotoxic effect (Kodama et al., 1982), as well as the acid-base balance and due to the negative effects on the regulation of ions (Senthil Murugan et al., 2008). Because medicinal leeches are among the endangered species (Sağlam, 2011; Sağlam et al., 2018; Ceylan, 2020; Kvist et al., 2020), determining the toxicologic limits becomes important to maintain sustainable management.

The southern medicinal leech, Hirudo verbana is used in various toxicological and pharmacological studies due to its sensitivity and easy housing features in laboratory conditions. It, as well as being a sensitive organism for ecotoxicological studies, is being used in the studies carried out in neurobiological, neuroethological, physiological, histological, microbiological fields and in many engineering disciplines (Petrauskienè, 2008a). The chronic lethal effects of zinc, copper, and their mixtures to medicinal leech Hirudo verbana were investigated by Petrauskienè (2008b). Although there is data on the chronic lethal effects, the acute toxicity of zinc and on $H$. verbana and the physiological and behavioral changes of the leeches belonging to the $H$. verbana that are exposed to the zinc is not known. It was aimed to reveal these yet unstudied data with the present study. Considering that southern medicinal leech, H. verbana is endangered and its populations are weakening day by day in both Europe and Turkey, it is hoped that data obtained will contribute to the management policies of the medicinal leech populations in nature and fill the gap in the literature.

\section{MATERIALS and METHODS}

\section{Leeches}

The study was conducted using a total of 112 medicinal leeches Hirudo verbana Carena 1820 that bred in the medicinal leech production unit of Eğirdir Fisheries Research Institute, Turkey. The bodyweight of leeches was determined as $3.01 \pm 0.09 \mathrm{~g}$. The leeches were assigned randomly to the experimental group, and it was confirmed that the weight of leeches in the experimental group was normally distributed $(P>0.05)$.

\section{Toxicity test}

$\mathrm{ZnSO}_{4} \cdot 7 \mathrm{H}_{2} \mathrm{O}$ (Merck) was used as the toxicant in the experiment. The toxicity test was conducted using the standard method that was applied by Çetinkaya (2005) and Petrauskienè (2008b). The stock solution was prepared by using distilled water. The $\mathrm{Zn}^{+2}$ trial concentrations were prepared in different 7 doses of $0.00 \mathrm{mg} / \mathrm{L}, 6.25 \mathrm{mg} / \mathrm{L}, 12.50 \mathrm{mg} / \mathrm{L}, 25.00 \mathrm{mg} / \mathrm{L}, 50.00 \mathrm{mg} / \mathrm{L}, 100.00 \mathrm{mg} / \mathrm{L}$ and 200.00 $\mathrm{mg} / \mathrm{L}$ by taking from the stock solution. The leeches were placed as 8 individuals with two replications into the 5L pet jars, filled with the solutions prepared in the concentrations. The jars were closed to prevent the leeches from moving away from the test environment. The experiment was performed using the semi-static test, the groups of controls and treatment concentrations were renewed at intervals of 24 hours, and the experiment was continued for 96 hours. The reactions of the leeches and mortality were recorded (Çetinkaya, 2005).

The temperature, dissolved oxygen concentration, $\mathrm{pH}$, alkalinity $\left(\mathrm{CaCO}_{3}\right)$, total water hardness $\left(\mathrm{CaCO}_{3}\right)$, and electrical conductivity were measured as $19.3{ }^{\circ} \mathrm{C}, 5.72 \mathrm{mg} / \mathrm{L}, 7.80,242 \mathrm{mg} / \mathrm{L}, 350$ $\mathrm{mg} / \mathrm{L}$, and $460 \mu \mathrm{S} / \mathrm{cm}$, respectively. 


\section{Statistical analyses}

$L C_{50}$ values for 24 hours, 48 hours, 72 hours, and 96 hours and the $L T_{50}$ values for each calculable concentration, within the $95 \%$ confidence limits, were determined using the Probit Regression analysis using IBM SPSS Statistics version 25.0 for Windows package software (IBM Corp., Armonk, NY, USA) (Lei and Sun, 2018; Navarrete et al., 2021).

\section{RESULTS}

Except for the defecation at the beginning of the experiment, it wasn't observed abnormal behavior, reaction, and death in the leeches of the control group and the $6.25 \mathrm{mg} / \mathrm{L}$ concentration during the study. In addition to the defecation, the common responses of the leeches in $12.50 \mathrm{mg} / \mathrm{L}$ and the higher concentrations were uncontrolled swimming, excess mucus secretion especially in the suckers (Figure 1 and Figure 2), vomiting blood (Figure 3), weakening of the grip strength in suckers, twisting, the deformations in the body (Figure 4 and Figure 5c), hemorrhage both on and surround of male genital organs and penile prolapse (Figure 6), hemorrhage in different parts of the body (Figure 5a, Figure 6a, Figure 7 and Figure 8), and wearing on the body walls (Figure 5b).

No death has been recorded in control and $6.25 \mathrm{mg} / \mathrm{L}$ groups during the experiment. It is observed that all leeches died in $25,50,100$, and $200 \mathrm{mg} / \mathrm{L}$ concentration groups and, while 5 of 16 leeches died in the $12.50 \mathrm{mg} / \mathrm{L}$ concentration group.

$L C_{50}$ values for 24 hours, 48 hours, 72 hours and 96 hours were $48.30 \mathrm{mg} / \mathrm{L}, 19.68 \mathrm{mg} / \mathrm{L}, 15.48$ $\mathrm{mg} / \mathrm{L}$ and $14.12 \mathrm{mg} / \mathrm{L}$, respectively. It is noted a decline in the $L C_{50}$ values as long as the zinc exposure time is extended. The $L C_{50}$ values and $95 \%$ confidence limits determined in the zinc acute toxicity test were presented in Table 1.

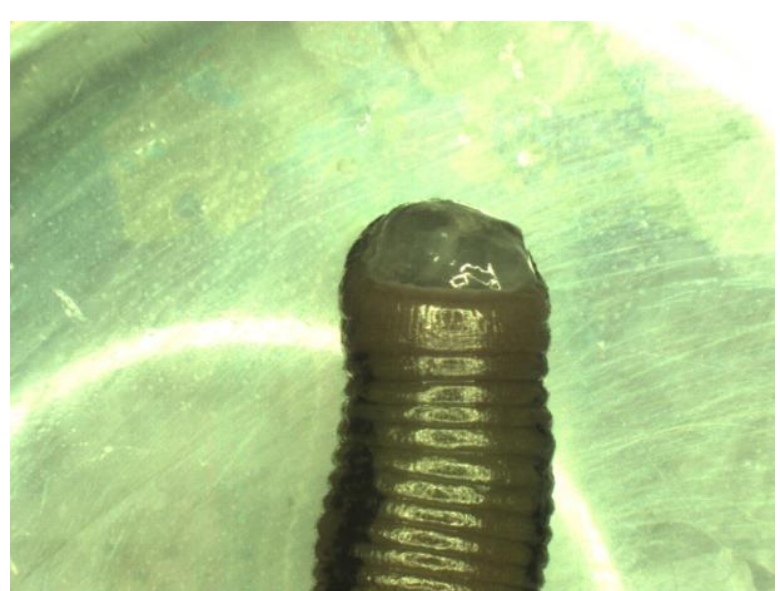

Figure 1. Excessive mucus secretion in the anterior sucker

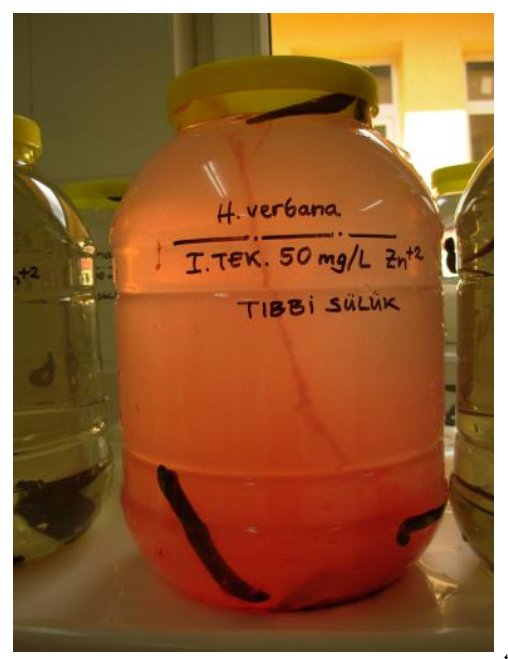

Figure 3. Blood vomiting observed in the $45^{\text {th }}$ minute of the experiment in $50 \mathrm{mg} / \mathrm{L} \mathrm{Zn}^{+2}$ concentration

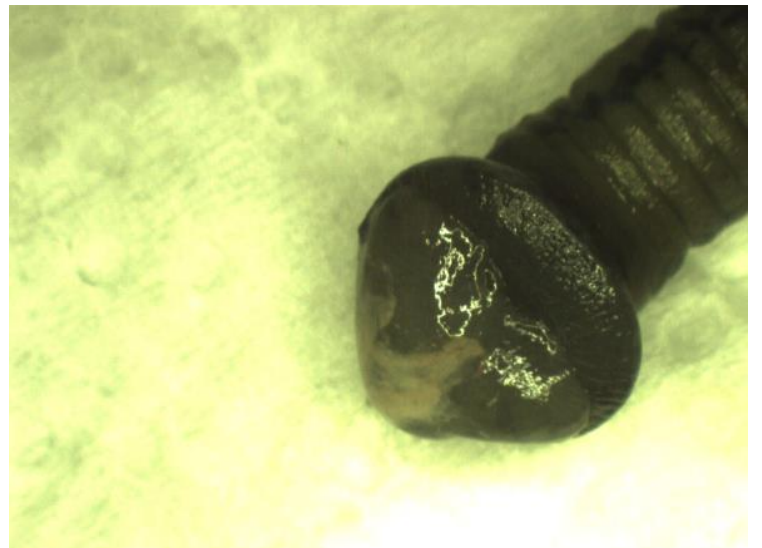

Figure 2. Excessive mucus secretion in the posterior sucker

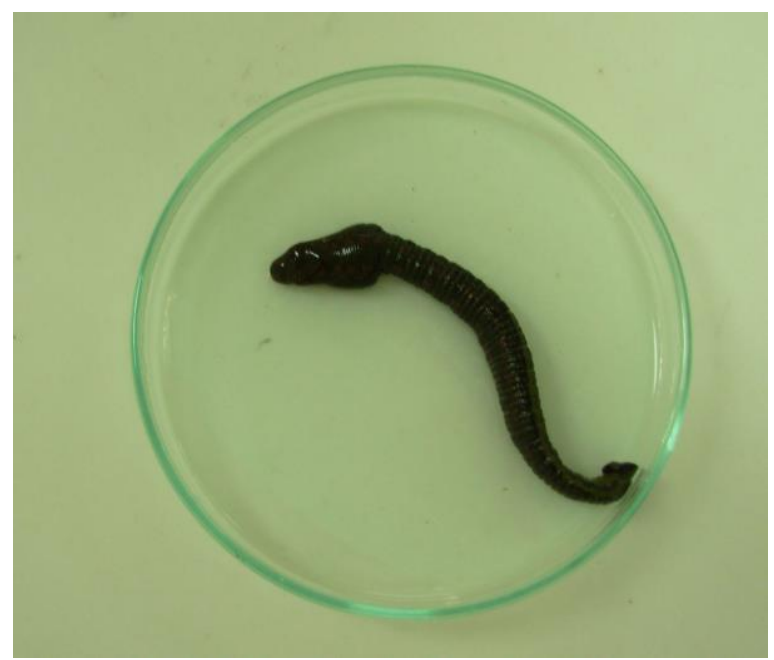

Figure 4. Morphological deformation in the anterior part of the leech 


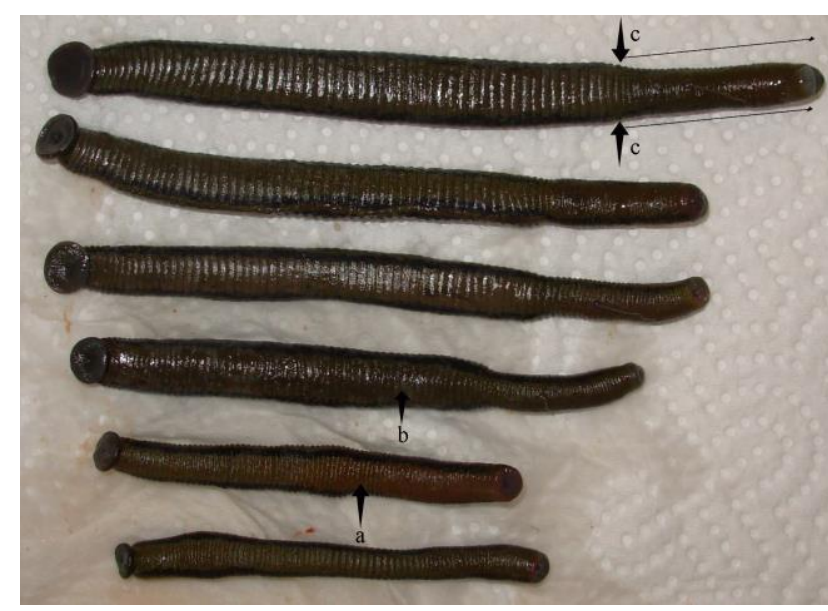

Figure 5. Hemorrhage in the ventral region of the leeches (a), wearing on the body wall (b), and deformation occurring in the anterior part (c)

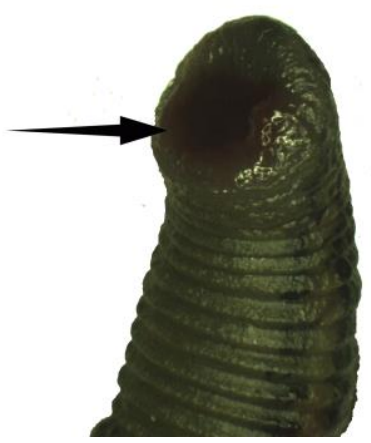

Figure 7. Hemorrhage on anterior sucker of $H$. verbana

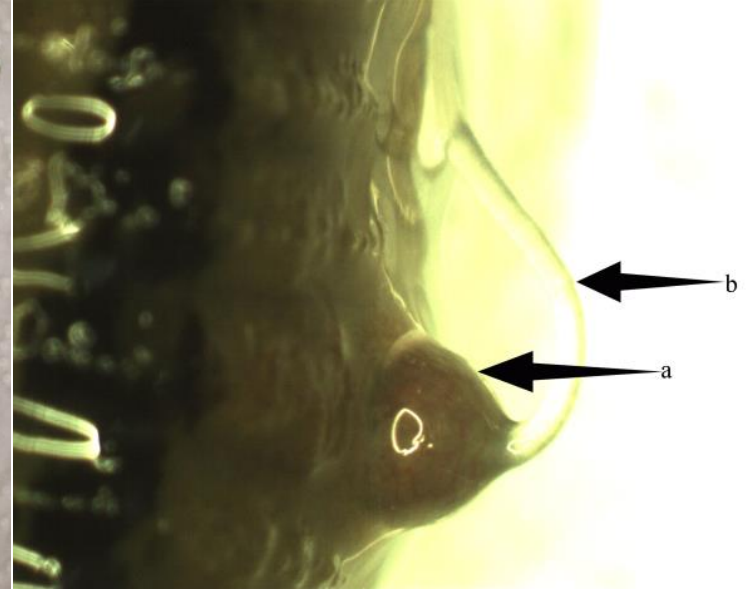

Figure 6. Hemorrhage on and around the male genital organ of $H$. verbana (a) and prolapse of the male genital organ (b)

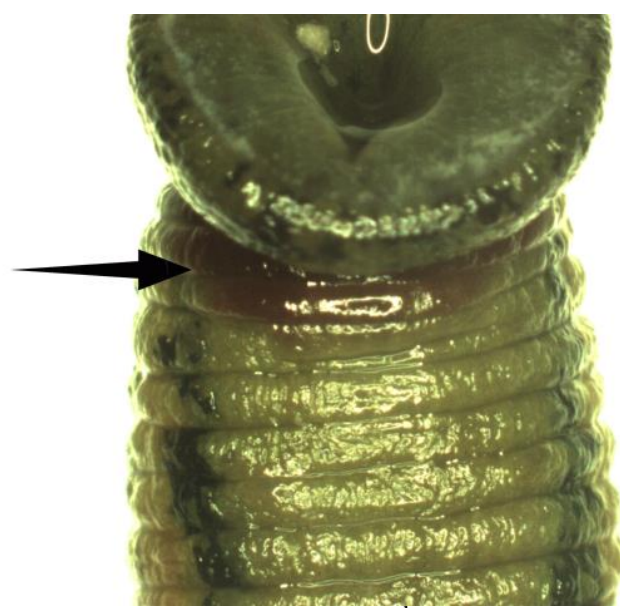

Figure 8. Hemorrhage in $27^{\text {th }}$ segment of $H$. verbana

Table 1. $L C_{50}$ values and $95 \%$ confidence limits in zinc acute toxicity test in medicinal leech, $H$. verbana.

\begin{tabular}{ccc}
\hline \hline Time (hour) & $\boldsymbol{L C}_{\boldsymbol{5} \boldsymbol{0}}(\mathbf{m g} / \mathbf{L})$ & $\mathbf{9 5 \%}$ confidence limits (hour) \\
\hline 24 & 48.30 & $14.81-66.92$ \\
48 & 19.68 & $14.89-22.19$ \\
72 & 15.48 & $12.86-19.15$ \\
96 & 14.12 & $11.75-17.66$ \\
\hline \hline
\end{tabular}

It was observed that $L T_{50}$ durations were shortened depending on the increased concentrations. $L T_{50}$ values were determined for $25 \mathrm{mg} / \mathrm{L}, 50 \mathrm{mg} / \mathrm{L}, 100 \mathrm{mg} / \mathrm{L}$ and $200 \mathrm{mg} / \mathrm{L}$ as 38.63 hours 24.55 hours 14.62 hours and 12.78 , respectively. $L T_{50}$ values and $95 \%$ confidence limits for these values are given in Table 2.

Table 2. $L T_{50}$ values and $95 \%$ confidence limits determined in zinc acute toxicity test in medicinal leech, H. verbana.

\begin{tabular}{ccc}
\hline \hline Concentrations $(\mathbf{m g} / \mathbf{L})$ & $\boldsymbol{L T}_{\boldsymbol{5} \boldsymbol{0}}$ (hour) & $\mathbf{9 5 \%}$ confidence limits (hour) \\
\hline 25 & 38.63 & $36.72-40.87$ \\
50 & 24.55 & $23.90-25.23$ \\
100 & 14.62 & $13.68-15.78$ \\
200 & 12.78 & $12.00-13: 80$ \\
\hline \hline
\end{tabular}




\section{DISCUSSION}

The leeches were exposed to $0.00 \mathrm{mg} / \mathrm{L}, 6.25 \mathrm{mg} / \mathrm{L} 12.50 \mathrm{mg} / \mathrm{L}, 25.00 \mathrm{mg} / \mathrm{L}, 50.00 \mathrm{mg} / \mathrm{L}, 100.00$ $\mathrm{mg} / \mathrm{L}$ and $200.00 \mathrm{mg} / \mathrm{L}$ zinc concentrations in the present study. The observed behavioral changes and abnormalities occurring in the bodies and deaths are recorded during this experiment continued for 96 hours.

Petrauskienè (2008b) investigated the chronic effects of zinc, copper, and their mixtures on medicinal leech $H$. verbana and given the $L C_{50}$ values for periods ranging from 48 hours to 30 days. $L C_{50}$ values were found $19.68 \mathrm{mg} / \mathrm{L}$ and $14.12 \mathrm{mg} / \mathrm{L}$, respectively for 48 hours and 96 hours in our study, however, in the mentioned study these values were $33.94 \mathrm{mg} / \mathrm{L}$ and $15.83 \mathrm{mg} / \mathrm{L}$, respectively. It is thought that the differences might be caused by the water quality of the test solution (ion concentration, $\mathrm{pH}$, water temperature, etc.) and the size of the leeches.

Sağlam and Şahin (2006) investigated the acute toxicity effect of copper sulfate $\left(\mathrm{CuSO}_{4} 5 \mathrm{H}_{2} \mathrm{O}\right)$ on medicinal leech $H$. medicinalis. The $L C_{50}$ values for 12 hours, 24 hours, 48 hours, 72 hours and 96 hours were found to be $0.2093 \mathrm{mg} / \mathrm{L}, 0.0878 \mathrm{mg} / \mathrm{L}, 0.0444 \mathrm{mg} / \mathrm{L}, 0.0261 \mathrm{mg} / \mathrm{L}$ and $0.0044 \mathrm{mg} / \mathrm{L}$, respectively. The $L T_{50}$ values for the $0.025,0.05$ and $0.1 \mathrm{mg} / \mathrm{L}$ concentrations were found to be 60h:10min, 34h:03min and 24h:15min, respectively. Considering the $L T_{50}$ values in 96 hours, the toxic effects of copper sulfate for medicinal leeches seem to be higher compared to zinc.

According to the previous studies, the $L C_{50}$ values vary over a wide range, the results of the previous acute toxicity studies on some aquatic organisms are presented in Table 3.

Table 3. $L C_{50}$ values in some aquatic organisms regarding zinc toxicity by comparing with the present study.

\begin{tabular}{|c|c|c|c|c|}
\hline Species & $96 \mathrm{~h} L C_{50}$ & $48 \mathrm{~h} L C_{50}$ & $24 \mathrm{~h} L C_{50}$ & References \\
\hline Salmo gairdneri & $1.9-3.0 \mathrm{mg} / \mathrm{L}$ & 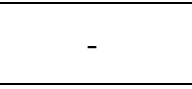 & 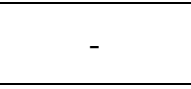 & $\begin{array}{l}\text { Holcombe and Andrew, } \\
1978\end{array}$ \\
\hline Mytilus edulis & $20.8 \mathrm{mg} / \mathrm{L}$ & - & - & Hietanen et al., 1988 \\
\hline Chalcalburnus tarichi & $16.02 \mathrm{mg} / \mathrm{L}$ & $17.13 \mathrm{mg} / \mathrm{L}$ & $17.09 \mathrm{mg} / \mathrm{L}$ & $\begin{array}{l}\text { Sönmez and Çetinkaya, } \\
2003\end{array}$ \\
\hline Capoeta fusca & $102.9 \mathrm{mg} / \mathrm{L}$ & - & - & Ebrahimpour et al., 2010 \\
\hline Pagrus major & $10.1 \mathrm{mg} / \mathrm{L}$ & $4.3 \mathrm{mg} / \mathrm{L}$ & - & Huang et al., 2010 \\
\hline Oreochromis niloticus & $72.431 \mathrm{mg} / \mathrm{L}$ & - & - & $\begin{array}{l}\text { Ezeonyejiaku and Obiakor, } \\
2011\end{array}$ \\
\hline Atherina boyeri & - & - & $1.768 \mathrm{mg} / \mathrm{L}$ & Bulut et al., 2013 \\
\hline Acipenser transmontanus & $0.150-0.625 \mathrm{mg} / \mathrm{L}$ & - & - & Vardy et al., 2014 \\
\hline Branchiura sowerbyi & $0.97 \pm 0.07 \mathrm{mg} / \mathrm{L}$ & - & - & Lobo et al., 2016 \\
\hline Tubifex tubifex & $8.7 \pm 0.84 \mathrm{mg} / \mathrm{L}$ & - & - & Lobo et al., 2016 \\
\hline Percocypris pingi & $2.852 \mathrm{mg} / \mathrm{L}$ & $2.933 \mathrm{mg} / \mathrm{L}$ & $3.504 \mathrm{mg} / \mathrm{L}$ & Zeng et al., 2018 \\
\hline H. verbana & $\begin{array}{l}15.83 \mathrm{mg} / \mathrm{L} \\
14.12 \mathrm{mg} / \mathrm{L}\end{array}$ & $\begin{array}{l}33.94 \mathrm{mg} / \mathrm{L} \\
19.68 \mathrm{mg} / \mathrm{L}\end{array}$ & $\begin{array}{c}- \\
48.30 \mathrm{mg} / \mathrm{L}\end{array}$ & $\begin{array}{l}\text { Petrauskienè, 2008b } \\
\text { The present study }\end{array}$ \\
\hline
\end{tabular}

Regarding the data given in Table 3, H. verbana is more resistant to zinc compared to silver fish, rainbow trout, Japanese seabream, white sturgeons, and tubificid worms, which to have the same sensitivity as pearl mullet and seems to be more sensitive compared to other species. This indicates that $H$. verbana has moderate sensitivity to zinc.

The initial responses of the leeches exposed to the zinc were defecation, excessive mucus secretion, and uncontrolled swimming. Defecation was the reaction that occurred in the first 10 minutes of the experiment, whereas uncontrolled swimming and excessive mucus secretion occurred in the first 20 minutes. The mucus secretion in the leeches exposed to the zinc concentration of $200 \mathrm{mg} / \mathrm{L}$ was transparent gel consistency; however, turned into red in jelly consistency when the leeches vomit digested blood. The examination was made on the dead leech from an external perspective, after removing them from the zinc solution. It was observed the presence of mucus strongly attached to the anterior and posterior suckers of some leeches (Figure 1 and Figure 2). In case of solution replacement made at 24-hour intervals, certain responses were not observed such as defecation, excessive mucus secretion, and uncontrolled swimming. Petrauskienè (2005) reported that the most sensitive responses of the leeches treated with crude oil were mobility and avoidance from the environment. Sağlam and Şahin (2006) stated that the mucus secretion was more intense in anterior and posterior suckers. 
The leeches had difficulty taking hold with their suckers and then fell to the bottom of the jars and began twisting movements in $200 \mathrm{mg} / \mathrm{L}$ concentration, especially within 30 minutes at the beginning of the experiment. It was recorded that their twisting movements were intensified on the bottom of the container after 40 minutes of the experiment beginning, and in continuation of this movement the leeches have lost the integrity of their body form and certain permanent deformations have occurred (Figure 4 and Figure 5c). Petrauskienè (2005) being consistent with our observation, reported that the body form of the medicinal leech $H$. medicinalis treated with crude oil changes due to the continuous contraction and relaxation of the muscles in certain segments. The deformation on the body walls of the leeches occurred also in another toxicity study made with copper (Kutlu et al., 2010).

The incidence of hemorrhage in the experiment was listed as follows: the anterior sucker $(67 \%)$, the ventral region of the body (61\%), male genital organs (32\%), and posterior sucker (29\%). Sağlam and Şahin (2006) reported that the hemorrhage occurred in different body parts of the leeches exposed to copper sulfate.

The toxicological studies performed with leeches became restricted due to the significant decrease in natural leech populations, therefore the cultivated leeches should be used for these studies (Petrauskienè, 2004). In the toxicity studies to be done, it would not be appropriate to use the rare species and reduce the required number of the individual to the minimum level for the other species.

In conclusion, although the concerns are expressed that the short-term heavy metal toxicity experiments will be insufficient to predict the environmental impact on invertebrates (Petrauskienè, 2008b), the low concentrations to be used in the studies to investigate the long-term chronic effects of the toxicant are likely to be inadequate to determine the lethal effects of the discharges of the high concentrations into the receiving environments. It is hoped that the $L C_{50}$ and $L T_{50}$ values, the physiological and behavioral changes defined as toxicity indicators will contribute to the studies to be made with $H$. verbana and zinc and will be useful for establishing standards and implementation of measures for the protection of medicinal leech populations in nature.

\section{REFERENCES}

Ayhan, H., \& Mollahaliloğlu, S. (2018). Tıbbi sülük tedavisi: Hirudoterapi. Ankara Medical Journal, 18(1), 141148 (in Turkish).

Boardman, R., \& McGuire, D.O. (1990). The role of zinc in forestry. I. Zinc in forest environments, ecosystems, and tree nutrition. Forest Ecology and Management, 37(1-3), 167-205.

Bulut, C., Çetinkaya, O., Kubilay, A., Akçimen, U., \& Ceylan, M. 2013. Acute toxicity of zinc $(\mathrm{Cu}+2)$ on sand smelt (Atherina boyeri, Risso, 1810). Süleyman Demirel University Journal of Natural and Applied Science, 17(3), 32-38.

Ceylan, M., Çetinkaya, O., Küçükkara, R., \& Akçimen, U. (2015). Reproduction efficiency of the medicinal leech Hirudo verbana Carena, 1820. Turkish Journal of Fisheries and Aquatic Sciences, 15(3), 411-418.

Ceylan, M., \& Çetinkaya, O. (2017). Investigation on the collection and economy of medicinal leeches from wetlands around Lake Eğirdir, Turkey. Türkiye Parazitoloji Dergisi, 41(2), 96-101.

Ceylan, M. (2020). Effects of maternal age on reproductive performance of the southern medicinal leech, Hirudo verbana Carena, 1820. Animal Reproduction Science, 218, 106507.

Çetinkaya, O. (2005). Akuatik Toksikoloji: Balık Biyodeneyleri. Balık Biyolojisi Araştırma Yöntemleri. Karataş M, editör. Balık Biyolojisi Araştırma Yöntemleri. Ankara: Nobel Yayın Dağıtım. p. 169-217 (in Turkish).

Ebrahimpour, M., Alipour, H., \& Rakhshah, S. (2010). Influence of water hardness on acute toxicity of copper and zinc on fish. Toxicology and Industrial Health, 26(6), 361-365.

Eisler, R. (1993). Zinc hazards to fish, wildlife, and invertebrates: A Synoptic Review. Biological Report 10, Laurel Maryland: U.S. Fish and Wildlife Service.

Ezeonyejiaku, C.D., \& Obiakor, M.O. (2011). Toxicological study of single action of zinc on tilapia species (Oreochromis niloticus). Online Journal of Animal and Feed Research, 1(4): 139-143.

Gödekmerdan, A., Arusan, S., Bayar, B., \& Saglam, N. (2011). Medicinal leeches and hirudotherapy. Türkiye Parazitoloji Dergisi, 35(4), 234-239.

Hietanen, B., Sunila, I., \& Kristofferson, R. (1988). Toxic effects of zinc on the common mussel Mytilus edulis L.(Bivalvia) in brackish water. 1. Physiological and histopathological studies. Annales Zoologici Fennici, 25, 341-347.

Holcombe, G.W., \& Andrew, R.W. (1978). The acute toxicity of zinc to rainbow and brook trout: comparisons in hard and soft water. US EPA, EPA-600/3-78-094, Duluth, USA.

Huang, W., Cao, L., Shan, X., Xiao, Z., Wang, Q., Dou, S. (2010). Toxic effects of zinc on the development, growth, and survival of red sea bream Pagrus major embryos and larvae. Archives of environmental contamination and toxicology, 58(1), 140-150. 
Kodama, M., Ogata, T., \& Yamamori, K. (1982). Acute toxicity of zinc to rainbow trout Salmo gairdneri. Bulletin of the Japanese Society of Scientific Fisheries, 48(8), 1055-1058.

Kori-Siakpere, O., \& Ubogu, E.O. (2008). Sublethal haematological effects of zinc on the freshwater fish, Heteroclarias sp. (Osteichthyes:Clariidae). African Journal of Biotechnology, 7(12), 2068-2073.

Kutlu, M., Tanatmış, M., İşcan, A., Ertorun, N., Çalım, M. (2010). Effect of copper on the body wall structures of the medicinal leech Hirudo verbana Carena, 1820. Fresenius Environmental Bulletin, 19(6), 11861190.

Kvist, S., Manzano-Marín, A., de Carle, D., Trontelj, P., \& Siddall, M. E. (2020). Draft genome of the European medicinal leech Hirudo medicinalis (Annelida, Clitellata, Hirudiniformes) with emphasis on anticoagulants. Scientific reports, $10(1), 1-11$.

Lei, C., \& Sun, X. (2018). Comparing lethal dose ratios using probit regression with arbitrary slopes. BMC Pharmacology and Toxicology, 19(1), 1-10.

Lemke, S., \& Vilcinskas, A. (2020). European medicinal leeches-new roles in modern medicine. Biomedicines, $8(5), 99$.

Lobo, H., Méndez-Fernández, L., Martínez-Madrid, M., Daam, M.A, \& Espíndola, E.L. (2016). Acute toxicity of zinc and arsenic to the warmwater aquatic oligochaete Branchiura sowerbyi as compared to its coldwater counterpart Tubifex tubifex (Annelida, Clitellata). Journal of Soils and Sediments, 16(12), 2766-2774.

Mishra, S., Bharagava, R.N., More, N., Yadav, A., Zainith, S., Mani, S., \& Chowdhary, P. (2019). Heavy metal contamination: an alarming threat to environment and human health. In: Sobti R., Arora N., Kothari R. (eds) Environmental Biotechnology: For Sustainable Future. Springer, Singapore.

Mumcuoglu, K.Y. (2014). Recommendations for the use of leeches in reconstructive plastic surgery. EvidenceBased Complementary and Alternative Medicine, 2014, 205929.

Navarrete, J., Wilson, P., Allsing, N., Gordon, C., Margolis, R., Schwartz, A. V., ... \& Sant, K. E. (2021). The ecotoxicological contaminant Tris (4-chlorophenyl) methanol (TCPMOH) impacts embryonic development in zebrafish (Danio rerio). Aquatic Toxicology, 235, 105815.

Özkul, C. (2008). Effect of industrialization on soil heavy metal concentrations in İzmit (Kocaeli) regions. Journal Applied Earthscience, 7(2), 1-9.

Petrauskienè, L. (2004). The medicinal leech as a convenient tool for water toxicity assessment. Environmental Toxicology, 19(4), 336-341.

Petrauskienè, L. (2005). Changes in behavioural and physiological indices of medicinal leech exposed to crude oil. Ekologija, 2005(2), 1-5.

Petrauskienè, L. (2008a). The use of the medicinal leech (Hirudo sp.) in ecotoxicological and other scientific research - a short review. Lauterbornia, 65, 163-175.

Petrauskienè, L. (2008b). Lethal effects of $\mathrm{Zn}, \mathrm{Cu}$ and their mixture on the medicinal leech (Hirudo verbana). Ekologija, 54(2), 77-80.

Sağlam, N., \& Şahin, A. (2006). Acut toxicity of cupper sulphate $\left(\mathrm{CuSO}_{4} 5 \mathrm{H}_{2} \mathrm{O}\right)$ on medical leech Hirudo medicinalis L. 1758. Ege University Journal of Fisheries \& Aquatic Sciences, 23(1/1), 123-125.

Sağlam, N. (2011). Protection and sustainability, exportation of some species of medicinal leeches (Hirudo medicinalis L., 1758 and Hirudo verbana Carena, 1820). Journal of FisheriesSciences.com, 5(1), 1-15.

Sağlam, N., Özbay, Ö., Demir, T., Balcı, M., Pala, A., \& Kılıç, A. (2018). Effect of water quality on monthly density variation of the endangered southern medicinal leech Hirudo verbana Carena, 1820 (Hirudinea: Arhynchobdellida: Hirudinidae). Acta Zoological Bulgarica, 70, 433-441.

Sağlam, N. (2018). The effects of environmental factors on leeches. Advances in Agriculture and Environmental Science, 1(1), 1-3.

Salgueiro, M.J., Zubillaga, M., Lysionek, A., Sarabia, M.I., Caro, R., De Paoli, T., Hager, A., Weill, R., \& Boccio, J. (2000). Zinc as an essential micronutrient: a review. Nutrition Research, 20(5), 737-755.

Senthil Murugan, S., Karuppasamy, R., Poongodi, K., \& Puvaneswari, S. (2008). Bioaccumulation pattern of zinc in freshwater fish Channa punctatus (Bloch.) after chronic exposure. Turkish Journal of Fisheries and Aquatic Sciences, 8(1), 55-59.

Shakouri, A., \& Wollina, U. (2021). Time to Change Theory; Medical Leech from a Molecular Medicine Perspective Leech Salivary Proteins Playing a Potential Role in Medicine. Advanced Pharmaceutical Bulletin, 11(2), 261-266.

Sobczak, N., \& Kantyka, M. (2014). Hirudotherapy in veterinary medicine. Annals of parasitology, 60(2), 89-92.

Sönmez, M., \& Çetinkaya, O. (2003). Çinko'nun $\left(\mathrm{Zn}^{+2}\right)$ İnci kefali (Chalcalburnus tarichi Palas, 1811) Üzerindeki Akut Toksisitesi. XII. Ulusal Su Ürünleri Sempozyumu. 413-418 (in Turkish).

Tchounwou, P.B., Yedjou, C.G., Patlolla, A.K., \& Sutton, D.J. (2012). Heavy metal toxicity and the environment. In: Luch A. (eds) Molecular, clinical and environmental toxicology. Experientia Supplementum, vol 101. Springer, Basel. 
Vardy, D.W., Santore, R., Ryan, A., Giesy, J.P., \& Hecker, M. (2014). Acute toxicity of copper, lead, cadmium, and zinc to early life stages of white sturgeon (Acipenser transmontanus) in laboratory and Columbia River water. Environmental Science and Pollution Research, 21(13), 8176-8187.

Wicklum, D., Smith, D.E.C., \& Davies, R.W. (1997). Mortality, preference, avoidance, and activity of a predatory leech exposed to cadmium. Archives of Environmental Contamination and Toxicology, 32(2), 178-183.

Willis, M. (1979). Analysis of the effects of zinc pollution on the macro-invertebrate populations of the Afon Crafnant, North Wales. Environmental Geochemistry and Health, 7(3), 98-109.

Zeng, L., Huang, L., Zhao, M., Liu, S., He, Z. (2018). Acute toxicity of zinc sulfate heptahydrate $(\mathrm{ZnSO} 4 * 7 \mathrm{H} 2 \mathrm{O})$ and copper (II) sulfate pentahydrate $\left(\mathrm{CuSO}_{4} * 5 \mathrm{H}_{2} \mathrm{O}\right)$ on freshwater fish, Percocypris pingi. Fisheries and Aquaculture Journal, 9(1), 1000240. 